Journal of Animal \& Plant Sciences, 31(5): 2021, Page: 1537-1541

ISSN (print): 1018-7081; ISSN (online): 2309-8694

https://doi.org/10.36899/JAPS.2021.5.0356

Short Communication

\title{
POPULATION DENSITY OF BLACK FRANCOLIN (FRANCOLINUS FRANCOLINUS L.) IN KALA CHITTA RANGE, PAKISTAN
}

\author{
A. Basit ${ }^{1}$, M. Anwar ${ }^{1}$, B. A. Rakha ${ }^{* 1}$, M. S. Ansari ${ }^{2}$, N. Munawar ${ }^{1}$ and A. Akhter ${ }^{* 1}$ \\ ${ }^{1}$ Department of Wildlife Management, Pir Mehr Ali Shah Arid Agriculture University Rawalpindi-46300, Pakistan; \\ ${ }^{2}$ Department of Zoology, Division of Science and Technology, University of Education, College Road, Township, \\ Lahore-54000, Pakistan \\ *Corresponding Author’s E-mail: bushrauaar@gmail.com; ali.akhter2@yahoo.com
}

\begin{abstract}
Black francolin or Black partridge (Francolinus francolinus L.) is distributed throughout Pakistan including Indus plains, Baluchistan, Punjab and Khyber Pakhtunkhwa provinces. Black francolin has been described as common or Least Concern in IUCN Red List of Threatened Species (2018). There was no documented information available on population density of Black francolin in various habitats of Kala Chitta hills of Pothwar region, Pakistan. Therefore, present study was designed to investigate the population of Black francolin in study area to devise conservation measures. Based on the reconnaissance survey, three representative sites were selected to estimate the population of black francolin in its potential habitat in Kala Chitta hills. Observations were taken by direct sighting using "Visual Encounter Method (VEM)". The observations were taken along three fixed transects, having a length of $300 \mathrm{~m}$ and width varying from 20 to $50 \mathrm{~m}$ were laid down at each site to record the birds on or near the line. Overall, population density of Black francolin was recorded $1.06 \mathrm{birds} / \mathrm{ha}$. Highest population density (2.19 birds/ha) was recorded in mountainous forest and associated grassland. While, population density of 0.84 and $0.15 \mathrm{birds} / \mathrm{ha}$ was recorded in open cultivated land and wetlands associated vegetation, respectively. It is concluded that Black francolin population density is affected by habitat characteristics in Kala Chitta Hills. Therefore, habitat characteristics must be considered while devising conservation plan for Black Francolin.
\end{abstract}

Key words: Francolinus francolinus, Population, Kala Chitta, wetlands, mountainous forest Published first online January 21, 2021

Published final August 07, 2021.

\section{INTRODUCTION}

Black francolin or Black partridge (Francolinus francolinus) is a medium-sized game bird belongs to family Phasianidae, order Galliformes has a worldwide distribution (Mahmood et al., 2010). Although population of the Black francolin is facing some threats locally but its population is considered stable (Birdlife International, 2015). The species is found in the various ecological zone of India, Kashmir, West Bengal and Nepal (Bump and Bump, 1964; Ali and Ripley, 1983; Heidari et al., 2009). Limited populations also recline in the USA (Mahmood et al., 2010). Black francolin is distributed throughout Pakistan including Indus plains, forests, sub mountainous tract, riverine forest, grasslands and agriculture ecosystem (Roberts, 1991; Mann and Chaudhry, 2000). It can be seen in dense vegetation, cultivated crops and grassland for feeding purposes in the dawn and dusk (Khan and Mian, 2013). Black francolin population in Pakistan is declining due to habitat loss, pesticide/herbicidal sprays and hunting (Johnsgard, 1988; Ghaemi, 1998; Mann and Chaudhry, 2000; Birdlife International, 2015).

Black francolin bred from April to July; the breeding season varies in different ranges (Sharif, 2014).
The nests are constructed on the ground. The female makes a shallow scrape, concealed with vegetation, very difficult to detect by predators (Khan, 2010; Birdlife International, 2015). The female lays 7-12 eggs and takes 18-21 days to incubate (Sharif, 2014). This species produces two clutches in a breeding season (Knorr, 2002). Black francolin plays important roles in ecosystem by spreading seeds of plants and pollination (IUCN, 2013). The Black francolin is one of the most valued game birds of Pakistan (Roberts, 1992; Riaz et al., 2011) due its delicate flavor and important source of bush meat for poor people of Asia (Fuller et al., 2000; Forcina et al., 2015). In many countries of Asia, Black francolin is reared for meat, eggs and cock fighting among birders (McGowan, 2002).

To our knowledge, no data is available on the population density of black francolin in various habitats of Kala Chitta hills of Pothwar region, Pakistan. The present study was carried out to estimate the population density of Black francolin in various habitats of Kala Chitta hills of Pothwar region, Pakistan from November 2016 to July 2017. 


\section{MATERIALS AND METHODS}

Study area: Kala Chitta hills extend about $20 \mathrm{~km}$ in breadth and $77 \mathrm{~km}$ in length. Its located at $33^{\circ} 7^{\prime}$ and $34^{\circ}$ $\mathrm{N}$ and $72^{\circ} 45^{\prime}$ and $73^{\circ} \mathrm{E}$, an elevation between $500 \mathrm{~m}$ to $2100 \mathrm{~m}$, above mean sea level (Arshad et al., 2014). It is one of the largest hill ranges in the Pothwar Plateau of Punjab province (Iqbal et al., 2012). Temperature ranges between $5^{\circ} \mathrm{C}$ to $43^{\circ} \mathrm{C}$. An average of $1425 \mathrm{~mm}$ per annum rainfall is recorded in the area (Arshad et al., 2014). The area falls under dry subtropical broad-leaved forest. Dominant plant species included Acacia modesta, Dalbergia sissoo, Justacia adhatoda, Dodonea viscosa and Olea ferruginea, etc. Dominant grasses are Cynodon dactylon, Cymbopogon jawarancusa and Crogrostis cynoneroides (Arshad et al., 2014). It supports thousands of populations of herbivores. People extract wood for fuel and livelihood purposes.

Kala Chitta hills supports diverse and plentiful variety of wildlife species consisting of Punjab urial (Ovis vignei punjabiensis), Chinkara (Gazella bennetti), Jackal (Canis aureus), Red fox (Vulpes vulpes), Hyena (Hyaena hyaena), Hare (Lepus capensis), Wild boar (Sus scrofa), Chukar partridge (Alectoris chukar), Grey francolin or partridge (Francolinus pondicerianus), Black francolin or partridge (Francolinus francolinus) (Iqbal et al., 2012), Buff striped keelback (Amphiesma stolatum), Indian spiny-tailed lizard (Uromastyx hardwickii) and Indus Valley bullfrog (Hoplobatrachus tigerinus) (Arshad et al., 2014).

Study design: The study was conducted from November 2016 to July 2017. After a reconnaissance survey, the study sites were selected in different habitat types including natural forest and associated grassland. Mixed type of vegetation having plant species of Acacia modesta, Dodonea viscosa, Olea ferruginea, Cynodon dactylon and Cymbopogon jawarancusa etc and open grassland with scattered trees and agricultural fields. All these three sites were different from each other by vegetation distribution. Potential habitat of black francolin had prominent vegetation of Ziziphus nummularia, Acacia modesta, Tamrix aphylla, Saccharum munja, Typha angustata, Phragmite karke and Panicum species (Khan and Mian, 2012). Information was also collected about water sources and evidence of the presence of bird by direct observation and supplementary information from local villagers and wildlife staff. At each study site, three different transects (300 $\mathrm{m}$ long and $20-50 \mathrm{~m}$ wide) were selected to avoid biasness and taken as replicates to cover maximum area as suggested by Gaston (1980).

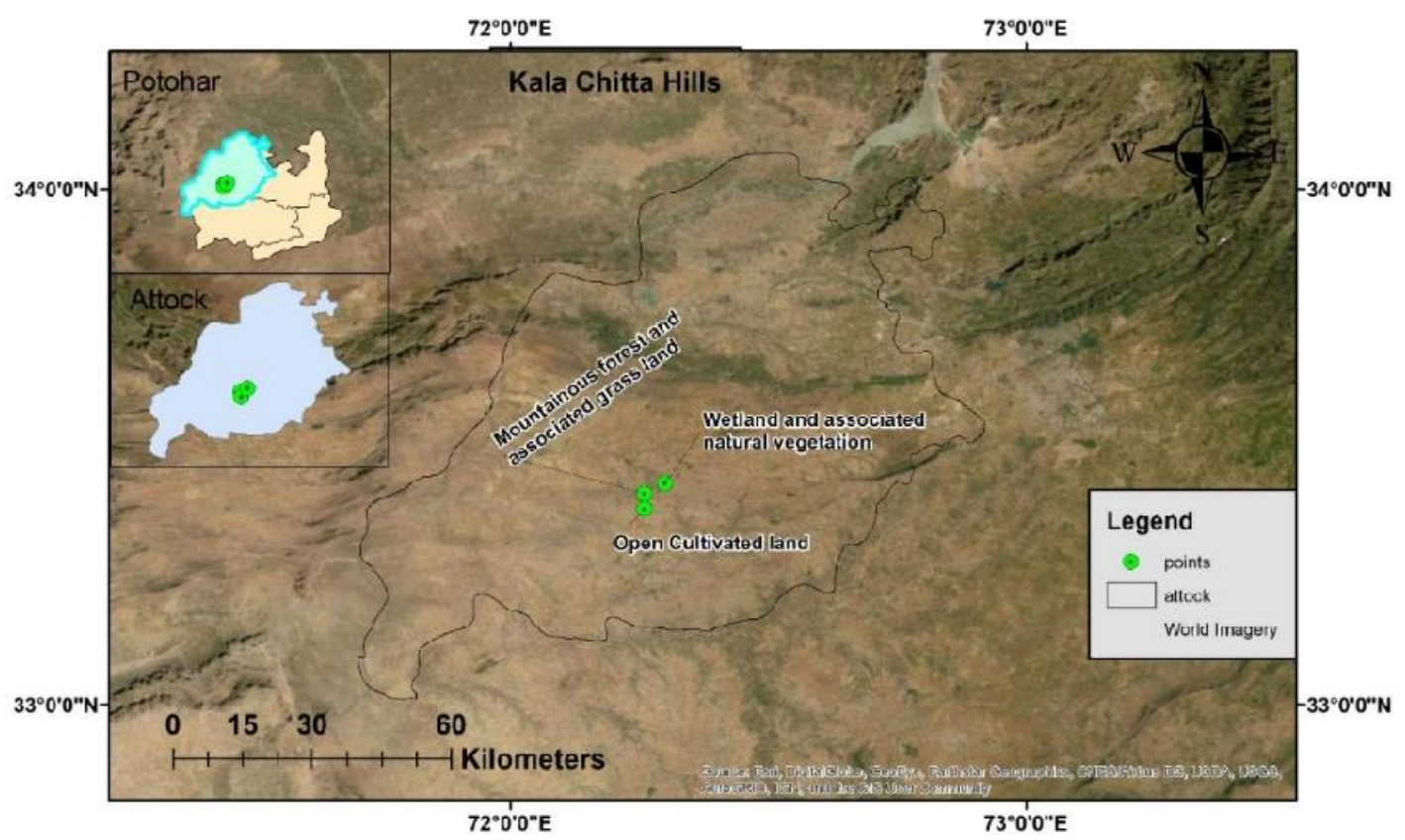

Fig 1. Map of Pothwar Plateau, showing location of study sites selected at Kala Chitta Range, Pakistan

Population estimation: For population estimation of black francolin in selected study sites, the observations were recorded by direct sighting using "Visual Encounter Method (VEM)". A binocular (10x) was used for detecting birds. The observations were taken along the selected transects to record the birds on or near the line (Gaston, 1980; Burnham et al., 1981). The population density of black francolin was calculated by using the following formula (Burnham et al., 1981).

Where,

$$
\mathrm{D}=\sum \frac{\mathrm{N}}{2 \mathrm{l}}
$$

$\mathrm{D}=$ Population density, $\mathrm{N}=$ Number of black partridges, $\mathrm{L}=$ Length of the transect line, $\mathrm{W}=$ Width of transect 
The surveys were conducted during the morning (from 05:00 to 09:00 hours during summer and from 06:30 to 10:30 hours during winter) and evening (from 16:00 to 19:00 hours during summer and from 15:00 to 18:00 hours during winter) (Mahmood et al., 2010). Indirect observations like fecal or feather observations were also recorded during surveys. The data were collected on parameters like; the estimated position of a bird at transect, altitude above mean sea level (m), habitat type, time spent in each observation of trail/transect, number of individuals of francolins species encountered and sighting time. Data recorded on different variables or study parameters within each site were analyzed using appropriate statistical method i.e. Students f-test, Analysis of Variance (ANOVA) and Kruskal-Wallis test.

\section{RESULTS AND DISCUSSION}

Highest population abundance of black francolin $(7.89 \pm 0.93)$ was recorded from the mountainous forest and associated grassland habitat followed by open cultivated land habitat $(4.56 \pm 0.84)$. While lowest population abundance was recorded in wetlands and associated natural vegetation habitat $(1.00 \pm 0.37)$. Highest numbers of black francolin were recorded in April (21) and March (19) (Table 1). Overall, population density of Black francolin was estimated 1.06 birds/ha. Highest population density (2.19 birds/ha) was recorded in mountainous forest and associated grassland. While, population density of 0.84 and $0.15 \mathrm{birds} / \mathrm{ha}$ was recorded in open cultivated land and wetland and associated natural vegetation, respectively (Table 2). Analysis of data revealed that population densities of black francolin were significantly different amongst three habitats of $(\mathrm{F}=$ 20.82, $\mathrm{P}=5.70$, d.f $=26$ ) at $\alpha=0.005$.

Table 1. Month-wise Population density (birds/ha) of Black Francolin recorded during different calendar months in Kala Chitta Hills of Pothwar region, Pakistan

\begin{tabular}{lccc}
\hline $\begin{array}{l}\text { Month/Study } \\
\text { site }\end{array}$ & $\begin{array}{c}\text { Mountainous forest and associated } \\
\text { grass land }\end{array}$ & $\begin{array}{c}\text { Open Cultivated } \\
\text { land }\end{array}$ & $\begin{array}{c}\text { Wetland and associated natural } \\
\text { vegetation }\end{array}$ \\
\hline 16-Nov & 3 & 1 & 0 \\
16-Dec & 5 & 4 & 2 \\
17-Jan & 8 & 4 & 0 \\
17-Feb & 7 & 6 & 1 \\
17-Mar & 9 & 7 & 3 \\
17-Apr & 12 & 9 & 0 \\
17-May & 11 & 5 & 1 \\
17-Jun & 9 & 2 & 0 \\
17-Jul & 7 & 3 & 2 \\
Mean \pm S.E & $\mathbf{7 . 8 9} \pm \mathbf{0 . 9 3}$ & $\mathbf{4 . 5 6} \pm \mathbf{0 . 8 4}$ & $\mathbf{1 . 0 0 \pm 0 . 3 7}$ \\
\hline
\end{tabular}

Table 2. Population density of Black Francolin in Kala Chitta Hills of Pothwar region, Pakistan

\begin{tabular}{lccc}
\hline \multicolumn{1}{c}{ Study Sites } & $\begin{array}{c}\text { Area of transects } \\
\text { (ha) }\end{array}$ & $\begin{array}{c}\text { Average number of } \\
\text { Black Partridge }\end{array}$ & $\begin{array}{c}\text { Population } \\
\text { density/ha }\end{array}$ \\
\hline Mountainous forest and associated grass land & 3.6 & 7.89 & 2.19 \\
Open Cultivated land & 5.4 & 4.56 & 0.84 \\
Wetland and associated natural vegetation & 6.3 & 1 & 0.15
\end{tabular}

For analysis of population density in three habitats type mountainous forest and associated grassland, open cultivated land and wetland, and associated natural vegetation the ANOVA was used for the equality of variances. From the results of f-test, the value was significantly different. Kruskal-Wallis test was applied for the medians of mountainous forest and associated grassland, open cultivated land and wetland and associated natural vegetation, the values obtained $(\mathrm{H}$ $=17.523 ;$ d.f $=2 ; \mathrm{P}=.0002$ ) were significantly different. Cramps and Simmons (1980) stated severely cold weather and snow as a limiting factor to the population of black francolin and drought as another threatening factor. Fluctuations in the dispersal of black francolin directed that the decline of vegetation cover plays the most significant role in decreasing its population size and range distribution (Heidari et al., 2009).

Khan and Mian (2013) reported the density of black francolin in Lal Suhanra National Park, Pakistan during different months and suggested a seasonal variation. Population densities were lower during the winter season and then started rising in summer from 
March to May. Khan et al. (1991) reported the population of black francolin in different habitats of Sandal Bar, District Faisalabad; including densities was determined as $1.8,0.7,4.6$ and 5.6 per hectare, in cropland, dry land, wetland and cropland along the wetland, respectively.

Khan et al. (2015) studied the population of black francolin in Mang Game Reserve Haripur, and suggested three different habitats for the species. The mean number of bird's population density was recorded as $1.28,2.43$ and 2.20 per $\mathrm{km}^{2}$ in grassland, hilly land and wetland respectively. Mahmood et al. (2010) estimated the average population density of black francolin as 0.06 birds/ha at Lehari Nature park, Punjab, Pakistan. This study was conducted in three habitat types, i.e., wild area with wetland, purely wild habitat and wild area with cropland. The most preferable habitat was the wild area associated with wetland by the bird having the highest density of $0.07 \mathrm{birds} / \mathrm{ha}$.

This species has great potential for game hunting because of its flavor and important source of bush meat for poor people in Asia (Fuller et al., 2000; Forcina et al., 2015). Meat of black francolins is locally praised as powerful aphrodisiac (Altaf et al., 2018). However, in Pakistan, Black Francolins are included in schedule-I and protected in the study area under Punjab Wildlife Acts and Rules, 1974. Game management of black francolin is being done by issuing special hunting licenses for specific days and illegal hunting is penalized by financial fines which may be up to few thousands rupees.

From all discussion, it is illustrated that black francolin preferred mountainous forest and associated grassland due to an elevated position, the rocky mountains and denser vegetated areas that provide food and shelter/cover to this species. However, open wetlands are located at a lower elevation and less vegetated increasing the threat of predation. Plant cover increases the safety of bird from hunting, severe cold and drought condition of weather and reduction of vegetation cover decreases the range distribution and population size of black francolin. Wetlands and associated natural vegetation habitat comprise of low elevated hills with scattered vegetations like Albizia lebbeck, Dodonaea viscosa, Opuntia stricta, Adiantum incisum, Parthenium hysterophorous, and Cymbopogon jwarancuse, etc also increasing the risk of predation in this area. It is concluded that Black francolin population density is affected by habitat characteristics in Kala Chitta Hills.

Conservation recommendations: Kala Chitta Hills provides a suitable habitat for Black francolin. For effective management of Black francolin in study area, habitat characteristics must be consider while devising conservation plan for Black Francolin.

Acknowledgments: We appreciate and thank wildlife staff, local community, and landowners for tremendous logistical support, field assistance and for allowing us to access on their properties. We also acknowledged anonymous reviewers who made very helpful comments on the paper.

Statement of conflict of interest: The authors declare that they have no competing interests.

\section{REFERENCES}

Ali, S. and S.D. Ripley (1983). Handbook of the Birds of India and Pakistan. Compact Edition. Bombay Natural History Society, Oxford University Press, New Delhi. Pp. 737.

Altaf, M., M. Umair, A.R. Abbasi, N. Muhammad and A.M. Abbasi (2018). Ethnomedicinal applications of animal species by the local communities of Punjab, Pakistan. J. Ethnobiol. Ethnomed. 14:55. https://doi.org/10. 1186/s13002-018-0253-4 PMID: 30111346.

Arshad, M., M. Ahmad, E. Ahmed, A. Saboor, A. Abbas and S. Sadiq (2014). An ethno- biological study in Kala Chitta hills of Pothwar region, Pakistan mutinomial logit specification. J. Ethnobiol. Ethnomed 10: 10-13.

Birdlife, I. (2015). Francolinus francolinus. The IUCN Red List of Threatened Species 2015. http://www.iucnredlist.org/details/22678719/0.

Bump, G. and J.W. Bump (1964). A study and review of the Black Francolin and the Gray Francolin. Spec. Sci. Rep. Wildl. (81). Bur. Sport Fish. Wildl., Washington, D. C. USA. pp. 460.

Burnham, K.P., D.R. Anderson and J.L. Laake (1981). Line transect estimation of bird population density using a Fourier series. In: Ralph C. J. and Scott J. M. (eds). Estimating the number of terrestrial birds. Studies in Avian Biology 6. Cooper Ornithology Society, Las Cruces. pp. 466-482.

Cramp, S. and K.E.L. Simmons (1980). Handbook of the birds of Europe Middle East and North Africa: the birds of the western Palearctic. 2. Hawks to Bustard. Oxford University Press, Oxford, Uk.

Forcina, G., M. Guerrini, H. van Grouw, B.K. Gupta, P. Panayides and P. Hadjigerou (2015). Impacts of biological globalization in the Mediterranean: unveiling the deep history of human-mediated gamebird dispersal. Proc Natl Acad Sci USA. 112:

3296-3301. https://doi.org/10.1073/pnas.1500677112 PMID: 25733899.

Fuller, R.A., J.P. Caroll and P.J.K. McGowan (2000). Partridges, quails, francolins, snowcocks, guinefowl and turkeys. Status survey and conservation action plan 2000-2004. WPA/BirdLife/SSC Partridges, Quails and 
Francolin Specialist Group. IUCN, The World Conservation Union, Gland, Switzerland; 2000. p. 63.

Gaston, A.J. (1980). Census techniques for Himalayan pheasants including notes on individual species. J. World Pheas Associ 5: 40-53.

Ghaemi, R. (1998). Ecological Survey of Black Francolin in Golestan Province. J. Evniron 10: 35-39.

Heidari, N., T. Arbabi, G. Noori and A. Shahriari (2009). Distribution, population and ecology of black francolin (Francolinus francolinus bogdanovi), on the Sistan Plain, in relation to plant coverage and drought. Podoces 4: 28-36.

Iqbal, M., M.Z. Saleem, M.A. Khan, M. Akhtar and K. Mahmood (2012). Urial (Mammalia, Bovidae, Caprini) from the Kala Chitta Range of northern Pakistan. Punjab Univ. J. Zoo 27: 61-73.

IUCN (2013). Red List of Threatened Species. Downloaded September, 18, 2014 at http://www.iucnredlist.org.

Johnsgard, P. (1988). The quails, partridges and francolins of the world, Oxford Univ. Press, London, U. K. pp. 352.

Khan, M.F., M.S. Awan, A.Q. Nayyer, K. Mehmood and M.N.K. Khattak (2015). Comparative study on the population and habitat of the Grey Francolin Francolinus pondicerianus and Black Francolin Francolinus francolinus in Mang Game Reserve, Haripur, Pakistan. J. Anim. Plant Sci. 25: 101-107.

Khan, M.S., R.A. Khan and M. Ishaque (1991). Studies on the biology, habitat, distribution pattern and food of the Black Partridge (Francolinus francolinus) Sandal Bar Punjab. Pakistan J. Anim. Plant Sci 1: 129-130.

Khan, W.A. (2010). Studies on the comparative ecology of the south Persian black partridge, (Francolinus francolinus henrici) and the northern grey francolin (Francolinus pondicerianus interpositus) in Lal Suhanra National Park, Bahawalpur, Punjab, Pakistan. (unpublished) Ph.D. thesis. PMAS Arid Agri. Univ., Rawalpindi, Pakistan. pp. 218.
Khan, W.A. and A. Mian (2012). Habitat Preferences of Black Francolin (Francolinus francolinus) in Lal Suhanra National Park, Pakistan. Pakistan J. Zool 44(6):1593-1601.

Khan, W.A. and A. Mian (2013). Population Biology of Black Francolin (Francolinus francolinus) with Reference to Lal Suhanra National Park, Pakistan. Pakistan J. Zool 45: 183-191.

Knorr, O. (2002). Black Francolin. www.willamatte.edu/ cla/classics/Aristophanes /BlackFrancolin.html

Mahmood, S., T. Mahmood, M. Rais, I.Z. Qureshi and M.S. Nadeem (2010). A Comparative Study on the Populations and Habitats of the Grey Francolin Francolinus pondicerianus and the Black Francolin Francolinus francolinus in Lehri Nature Park, Punjab, Pakistan. Podoces 5: p. 42-53.

Mann, M.A. and A.A. Chaudhary (2000). Francolins in irrigated forest plantations and Submountainous tract of the Punjab, Pakistan. Pakistan Vet. J 20: 118-122.

McGowan, P. (2002). The conservation implications of the hunting of galliformes and the scollection of their eggs. In: S. A. Manika and M. Trivedi (eds.). Links between biodiversity conservation, livelihood and food security: the sustainable use of wild species for meat. Gland, Switzerland and Cambridge, UK: IUCN. p. 85- 93.

Riaz, M., A.A. Khan, M. Babar, N. Akhtar, S. Muhammad and I. Khaliq (2011). High genetic diversity revealed by RAPD markers in the Black Francolin (Francolinus francolinus, Galliformes) of Pakistan. Pakistan J. Zool. 43: 889-896.

Roberts, T.J. (1991). The Birds of Pakistan. I. Regional studies and non-passeriformes. Oxford Univ. Press. Karachi, Pakistan. pp. 598.

Roberts, T.J. (1992). The birds of Pakistan. I (NonPasserines). Oxford University Press.

Sharif, H.S.A. (2014). Black Francolin Francolinus francolinus in Bangladesh: Breeding biology, Status, Threats and conservation. Forktail 30: 142-143. (Short notes). 